ACTA UNIVERSITATIS LODZIENSIS

FOLIA LITTERARIA POLONICA 4(34) 2016

http://dx.doi.org/10.18778/1505-9057.34.17

\title{
PRACE EDYTORSKIE
}

\author{
Beata Bednarek ${ }^{*}$
}

\section{Kolacjonowanie przekazów wierszy Franciszka Dionizego Kniaźnina na podstawie wybranych liryków zawartych w autografie poety - dylematy edytorskie}

Za podstawę przygotowywanego wydania krytycznego liryków Franciszka Dionizego Kniaźnina przyjęto rękopis sporządzony przez poetę niezwykle starannie w latach 90. XVIII wieku, zatytułowany Poezje Franciszka Dionizego Kniaźnina ręka własna pisane 1 . Na ów autograf składają się dwa tomy, z których pierwszy mieści w sobie dwanaście ksiąg liryków, Żale Orfeusza nad Eurydyka, poematy oraz bajki, drugi zaś - utwory dramatyczne, Pieśni Anakreona, Carmina (wiersze łacińskie), Pieśni Osjana. Opracowywana edycja będzie obejmowała wszystkie liryki Kniaźnina z ksiąg od pierwszej do czwartej, ułożone w takim porządku, jaki nadał im w rękopisie autor.

Większość wierszy zawartych w tej części Poezji... ręka własna pisanych została opublikowana we wcześniejszych tomikach poetyckich Kniaźnina. W latach 1773-1777 utwory poety drukowane były także w ,Zabawach Przyjemnych i Pożytecznych", jednak wśród nich znalazł się pierwowzór tylko jednego liryku zawartego później w czterech początkowych księgach autografu². Pierwowzory aż siedmiu zamieszczonych w tych księgach liryków odnaleźć można natomiast na kartach pierwszego zbiorowego wydania dzieł puławskiego twórcy, czyli dwutomowych Erotyków z 1779 roku, które ukazały się w Warszawie nakładem Dru-

${ }^{*}$ Doktorantka, Uniwersytet Łódzki, Wydział Filologiczny, Instytut Filologii Polskiej, Katedra Edytorstwa, ul. Pomorska 171/173, 91-404 Łódź; e-mail: beatkaprokopczyk@gmail.com

${ }^{1}$ Autograf ten znajduje się w Bibliotece Książąt Czartoryskich w Krakowie (rkps sygn. 2223), jednak dostępny jest także w formie publikacji książkowej przygotowanej przez wydawnictwo Collegium Columbinum - Poezyje Franciszka Dyjonizego Kniaźnina ręka własna pisane, t. 1-2, druk pomocniczy do zdjęć cyfrowych rękopisu Fundacji Książąt Czartoryskich przy Muzeum Narodowym w Krakowie, Kraków 2006, Biblioteka Tradycji, nr 57 (w kolejnych przypisach i niektórych fragmentach tekstu głównego: A).

${ }^{2}$ Zob. F.D. Kniaźnin, Miłość, Wierność, „Zabawy Przyjemne i Pożyteczne” 1773, t. 8, cz. 2, s. 368. 
karni Jego Królewskiej Mości³. Publikacja ta, wpisująca się w nurt twórczości rokokowej, składa się łącznie z trzystu siedemdziesięciu utworów.

Następnym tomem Kniaźnina były Wiersze, wydane w 1783 roku w drukarni Michała Grölla (zawierające wierszowaną dedykację, siedemdziesiąt cztery liryki, wśród nich także przeredagowane utwory z poprzedniego wydania, oraz pierwodruk Żalów Orfeusza nad Eurydyka), które - biorąc pod uwagę nie tylko czas powstania, ale także ich kształt literacki - można postrzegać jako pomost pomiędzy Erotykami a kolejnymi zbiorowymi pracami twórcy ${ }^{5}$. W przygotowywanych obecnie do druku księgach autografu z lat 90. poeta zamieścił piętnaście liryków opublikowanych w tomie Wiersze.

W latach 1787-1788 wydane zostały trzy tomy dzieł Kniaźnina pt. Poezje. Edycja zupetna ${ }^{6}$. Zbiór ten obejmował między innymi sto siedem liryków, wśród których znalazły się także zmienione, poprawione utwory z Erotyków i Wierszy. Jest to ostatni drukowany przekaz utworów Kniaźnina. W czterech początkowych księgach Poezji... ręka własna pisanych autor zawarł siedemdziesiąt trzy liryki, pochodzące $\mathrm{z}$ tej publikacji, wprowadzając do tekstów większości z tych wierszy pewne poprawki redakcyjne. We wspomnianych księgach rękopisu Kniaźnin zamieścił także pięć wierszy, które przedtem nie zostały opublikowane w żadnym ze zbiorowych wydań jego poezji.

Podczas przygotowywania edycji krytycznej liryków Kniaźnina wydawca niejednokrotnie ma do czynienia z trzema czy nawet czterema wariantami tego samego utworu. Zestawienie ich ze sobą jest bardzo interesującym zadaniem, głównie ze względu na stopień i charakter ingerencji autora w teksty przed zamieszczeniem ich w kolejnych zbiorach poezji. Poprawki odzwierciedlają zmiany zachodzące w technice twórczej poety oraz dają obraz kształtowania się jego warsztatu pisarskiego, światopoglądu, uczuć, sytuacji i postawy życiowej’. Kolacjonowanie wariantów danego testu jest tyleż ciekawe, co pracochłonne i zajmujące. Należy tu zauważyć, że autor dokonywał nie tylko przekształceń typu stylistycznego, składniowego, leksykalnego czy zmian w zakresie pisowni. Nierzadko wprowadzał poprawki redakcyjne, zmieniał format wersyfikacyjny wierszy oraz pary rymowe, rezygnował z niefortunnych, nietrafnych (jego zdaniem) zwrotów oraz z wielosłowia, ograniczając powtarzanie wybranych wyrazów czy treści, w wyniku czego poszerzał lub skracał teksty o obszerne fragmenty. Warto również zwrócić uwagę na fakt, że na skutek wprowadzania tych poprawek niejednokrot-

${ }^{3}$ Tanże, Erotyki, t. 1-2, wyd. w Drukarni Nadwornej J. K. Mci, Warszawa 1779 (w kolejnych przypisach oraz w niektórych miejscach wywodu: E).

${ }^{4}$ Tenże, Wiersze, t. 1, wyd. nakładem i drukiem M. Grölla, Księgarza Nadwornego J. K. Mci, Warszawa 1783 (w kolejnych przypisach oraz w niektórych fragmentach wywodu: W).

${ }^{5}$ Por. L. Kalisz, Liryka Kniaźnina a poezja klasyczna, „Pamiętnik Literacki” 1924/25, R. XXI, s. 44.

${ }^{6}$ F. D. Kniaźnin, Poezje. Edycja zupetna, t. 1-3, wyd. w Drukarni uprzywilejowanej M. Grölla, Księgarza Nadwornego J. K. Mci, Warszawa 1787-1788 (w kolejnych przypisach i w wybranych fragmentach tekstu głównego: EZ).

${ }^{7}$ L. Kalisz, dz. cyt., s. 47. 
nie cała wypowiedź podlegała zmianom semantycznym ${ }^{8}$. Częstym zabiegiem redakcyjnym stosowanym przez Kniaźnina było także nadawanie wierszom nowych tytułów oraz zamieszczanie w jednym zbiorze kilku utworów zatytułowanych tak samo, co stanowi dla edytora dodatkowe drobne utrudnienie.

Egzemplifikacji zabiegów autora, polegających na dążeniu do ekonomii wypowiedzi, dostarcza między innymi utwór Do Chryzala ${ }^{9}$, w pierwodruku z Wierszy liczący trzy strofy, natomiast w kolejnych zbiorach już tylko dwie ${ }^{10}$. Dzięki usunięciu końcowych czterech wersów, łagodzących wymowę całości, może zbyt dosłownych i tkliwych, utwór zyskał na atrakcyjności i nabrał bardziej ascetycznego charakteru. Inne przykłady wierszy, w których poeta zrezygnował z jednej lub kilku strof, to: Do Mirtu ${ }^{11}$, Piorun ${ }^{12}$, Matka Obywatelka ${ }^{13}$, O Chloi ${ }^{14}$, Babia Góra. Do Pawła Czenpińskiego, gdy objeżdżat góry krakowskie ${ }^{15}$ (tytuły utworów podaję zgodnie z pierwodrukiem). Amplifikacje, rzadziej dokonywane przez autora, podyktowane były niekiedy, jak w przypadku omówionych przez Tadeusza Mikulskiego wariantów Ody do wąsów ${ }^{16}$, chęcią rozwinięcia, rozbudowania dawnego pomysłu. Innym razem zaś wiązały się z potrzebą przypisania utworu konkretnemu adresatowi, co wymagało odwołania się do jego osoby lub związanej z nim sytuacji. Przykładem może być Pieśń Homera ${ }^{17}$, poprzedzona później trzema nowymi strofami, traktującymi o zdarzeniu z życia Jana Kłokockiego ${ }^{18}$, i właśnie jemu dedykowana. Warte rozpatrzenia są powody podejmowania takich działań w przypadku każdego wiersza, jednak zagadnienie to nie stanowi przedmiotu niniejszych rozważań i wymaga osobnego opracowania.

Odnotowanie w aparacie krytycznym odmian tego typu utworów nie stanowi większego problemu, jako że oprócz wymienionych powyżej, często spotykanych zmian redakcyjnych, edytor musi po prostu uwzględnić dopisane w podstawie wyda-

${ }^{8}$ T. Kostkiewiczowa, Kniaźnin jako poeta liryczny, Zakład Narodowy im. Ossolińskich Wydawnictwo Polskiej Akademii Nauk, Wrocław-Warszawa-Kraków-Gdańsk 1971, s. 42-68.

${ }^{9}$ Zob. F. D. Kniaźnin, Do Chryzala, w: W, s. 47.

${ }^{10}$ Por. dwa późniejsze warianty utworu: tenże, Do Chryzala. Starego bogacza, w: EZ, t. 1, s. 217; tenże, Do Chryzala, w: A, s. 37.

${ }^{11}$ Por. tenże, Do mirtu, w: W, s. 48-50; tenże, Do mirtu, w: EZ, t. 1, s. 199-200; tenże, Do mirtu, w: A, s. 34-35.

${ }^{12}$ Por. tenże, Piorun z Tompsona, w: W, s. 60-62; tenże, Piorun. Obraz wzięty z Thompsona, w: EZ, t. 1, s. 95-97; tenże, Piorun z Tompsona, w: A, s. 18-19.

${ }^{13}$ Por. tenże, Do dziecięcia. Czułość matki, w: W, s. 150-152; tenże, Matka obywatelka, w: EZ, t. 1, s. 87-89; tenże, Matka obywatelka, w: A, s. 15-16.

${ }^{14}$ Por. tenże, $O$ Chloi, w: W, s. 30-32; tenże, Do serca o Chloi, w: EZ, t. 1, s. 13-15; tenże, Do serca o Chloi, w: A, s. 23.

${ }^{15}$ Por. tenże, Babia Góra. Do Pawła Czenpińskiego, gdy objeżdżat góry krakowskie, w: EZ, t. 1, s. 132-136; tenże, Do Pawła Czenpińskiego. Babia Góra, w: A, s. 25.

${ }^{16}$ T. Mikulski, Nad tekstami Kniaźnina, w: tegoż, W kręgu oświeconych, Państwowy Instytut Wydawniczy, Warszawa 1960, s. 251-308.

${ }^{17}$ F. D. Kniaźnin, Pieśń Homera, w: W, s. 38-39.

${ }^{18}$ Zob. tenże, Do Jana Kłokockiego, w: EZ, t. 1, s. 63-65. 
nia lub nieumieszczone w niej fragmenty przygotowywanych do druku tekstów. Wśród opracowywanych edytorsko liryków Kniaźnina znajduje się jednak także kilka takich utworów, które diametralnie różnią się od pierwodruku zamieszczonego w pierwszych zbiorach poety, a końcowa wersja jest wynikiem daleko idących zmian wprowadzanych podczas każdej kolejnej redakcji tekstu. W rękopisie odnajdziemy takie wiersze (zwłaszcza pochodzące z Erotyków), w przypadku których autor wykorzystał tylko kilka fragmentów pierwszego przekazu oraz inaczej opracował główny temat, wątek czy pomysł. Przykładów takich tekstów nie brakuje wśród liryków zamieszczonych w czterech początkowych księgach autografu, stanowiącego swoisty testament poetycki Kniaźnina. Wystarczy porównać choćby poprzednie edycje ód: Do ks[iędza] Ign[acego] Nagurczewskiego. Kaskada ${ }^{19}$, O Elizie $^{20}$, O Filorecie $^{21}$ czy Do Anny Świętorzeckiej. Dwie siostry ${ }^{22}$. W tych okolicznościach wydawca musi zastanowić się nad optymalnym rozwiązaniem w kwestii kolacjonowania tak różnych od siebie przekazów, jako że zastosowanie metody tradycyjnej może okazać się niemożliwe.

By w pełni zrozumieć edytorskie dylematy związane z przygotowaniem wydania (a w szczególności aparatu krytycznego) tego rodzaju wierszy, należy prześledzić relacje zachodzące pomiędzy kolejnymi odmianami tekstów. W celu dokładnego zobrazowania omawianego tu zjawiska przyjrzyjmy się wariantom dwóch wymienionych liryków, pochodzących z drugiej księgi Poezji... ręka własna pisanych - ody O Filorecie, opatrzonej numerem dziewiątym, oraz Do Anny Świętorzeckiej. Dwie siostry, będącej szesnastym z kolei utworem zamieszczonym w tej części zbioru. Oba wiersze wielokrotnie były poddawane redakcji autorskiej, w wyniku czego edytor dysponuje czterema przekazami pierwszego z nich i pięcioma drugiego.

Zamieszczona w autografie oda $O$ Filorecie w pierwodruku, który odnajdujemy w IX księdze Erotyków, nosi tytuł Grób Klimeny ${ }^{23}$ i składa się z trzech strof czterowersowych pisanych jedenastozgłoskowcem. W kolejnych wydaniach poeta zmienił kształt wersyfikacyjny utworu, skracając go do formatu ośmiozgłoskowego. W zbiorze Wiersze przekształcił go w tetrastych, zatytułowany po prostu Nadgrobek ${ }^{24}$. Z poprzedniej wersji Kniaźnin przeniósł tu tylko ostatnią strofę i wprowadził do niej liczne zmiany:

Ktokolwiek tędy z was trafem pobieży, młode dziewczęta i chłopcy pospołu, westchnijcie z żalem: „Tu Klimena leży! Niegdyś serc nęta, teraz garść popiołu”. (Grób Klimeny, E, w. 9-12)
Stój! Filoreta tu leży, uroda $\mathrm{z}$ cnotą pospołu. Niegdyś ponęta młodzieży, a teraz garstka popiołu. (Nadgrobek, W)

\footnotetext{
${ }^{19}$ Tenże, Do ks[iędza] Ign[acego] Nagurczewskiego. Kaskada, w: A, s. 20.

${ }^{20}$ Tenże, $O$ Elizie, w: A, s. 9.

${ }^{21}$ Tenże, O Filorecie, w: A, s. 15.

${ }^{22}$ Tenże, Do Anny Świętorzeckiej. Dwie siostry, w: A, s. 18.

${ }^{23}$ Tenże, Grób Klimeny, w: E, t. 2, s. 243.

${ }^{24}$ Tenże, Nadgrobek, w: W, s. 158.
} 
W Poezjach. Edycji zupetnej oraz w rękopisie wszystkie liryki opatrzone zostały nazwą gatunkową, uznawane są za ody. Jak zauważa Teresa Kostkiewiczowa, wprowadzone do tych utworów modyfikacje można interpretować jako próbę zbliżenia wiersza do idealnego wzoru ody klasycystycznej ${ }^{25}$. Starania te są widoczne również w przypadku wiersza Nadgrobek, który - jako utwór zatytułowany $O$ Filarecie - w następnym wydaniu (z 1787 roku) ${ }^{26}$, ,poprzedzony zostaje [...] dwiema strofami uwznioślającymi wypowiedź przez wprowadzenie rozbudowanej o porównanie apostrofy i retorycznego pytania"27, a później w takim właśnie brzmieniu pojawia się także w autografie. Rozszerzenie utworu o dwie dodatkowe strofy może też służyć uzupełnieniu treści, wprowadzeniu czytelnika w realia przedstawionej przez poetę sytuacji. Tetrastych z wcześniejszych Wierszy (1783) sprawia bowiem wrażenie utworu niepełnego, wyrwanego z szerszego kontekstu, pozbawionego znamion refleksyjności.

Prześledzenie poprawek wprowadzonych do wariantów tego utworu pozwala wskazać szereg charakterystycznych zmian zachodzących w poetyce Kniaźnina. Widoczne są tu: rezygnacja ze sztafażu mitologicznego i antycznego ${ }^{28}$ (tylko w pierwodruku pojawiają się Hymen i Persefona oraz motyw palenia zwłok na stosie), a w efekcie - ewolucja estetyczna skierowana ku swojskiej sielskości ${ }^{29}$ (znamienna wydaje się tu zmiana imienia głównej bohaterki - Klimena to konwencjonalne imię greckie, kojarzone $\mathrm{z}$ okeanidą, żoną tytana Japeta ${ }^{30}$, popularne również w twórczości oświeceniowej, oznaczające zwykle uroczą, naiwną, wstydliwą, niekiedy także doznającą rozkoszy zmysłowych pasterkę ${ }^{31}$, natomiast Filoreta przywodzi tutaj na myśl sielankę XVII Józefa Bartłomieja Zimorowica o takim właśnie tytule, której dominantą tematyczną jest rozdzielenie małżonków przez śmierć i opłakiwanie przez męża zmarłej żony ${ }^{32}$ ), odstąpienie od opisów wyglądu zewnętrznego na rzecz eksponowania cech charakteru ${ }^{33}$, usuwanie zbyt dosadnych lub niezręcznych stwierdzeń, rezygnacja z konwencjonalizacji, teatralizacji i sztuczności wypowiedzi, dążenie do delikatności leksykalnej. Co interesujące, główny temat wiersza we wszystkich wariantach pozostaje niezmienny: mowa tu

${ }^{25}$ T. Kostkiewiczowa, dz. cyt., s. 67.

${ }^{26}$ F. D. Kniaźnin, O Filorecie, w: EZ, t. 1, s. 81.

${ }^{27}$ T. Kostkiewiczowa, dz. cyt., s. 67.

${ }^{28}$ Tamże, s. 58-59, 64.

${ }^{29}$ T. Mikulski, dz. cyt., s. 265.

${ }^{30}$ P. Grimal, Słownik mitologii greckiej i rzymskiej, przeł. M. Bronarska, B. Górska, A. Nikliborc, J. Sachse, O. Szarska, red. nauk. J. Łanowski, Zakład Narodowy im. Ossolińskich, Wrocław 1987, s. 186.

${ }^{31}$ E. Rabowicz, Stanisław Trembecki w świetle nowych źródeł, Zakład Narodowy im. Ossolińskich, Wrocław-Warszawa-Kraków 1965, s. 192.

${ }^{32}$ Zob. J. B. Zimorowic, Sielanki nowe ruskie, oprac. L. Szczerbicka-Ślęk, Zakład Narodowy im. Ossolińskich, Wrocław 1999, s. 174-190, BN I 287.

${ }^{33}$ T. Kostkiewiczowa, dz. cyt., s. 61. 
o śmierci i nagrobku urodziwej, młodej dziewczyny, o przemijaniu, rozumianym jako nietrwałość ludzkiego życia oraz ulotność piękna.

Zastanawia przy tym fakt, dlaczego Kniaźnin postanowił powrócić właśnie do tego utworu, jako jednego z nielicznych, i opublikować go w późniejszych zbiorach poezji. Być może decyzja ta wiązała się z chęcią upamiętnienia kogoś z otoczenia poety. Wskazywałaby na to kondensacja wypowiedzi, przybierającej po pierwszej redakcji formę zwięzłego nagrobnego napisu, mającego zwrócić uwagę przechodnia i skłonić go do chwili zadumy, a także zmiana imienia zmarłej, czyli zabieg, który można interpretować jako próbę uniknięcia asocjacji między utworem a jego poprzednią wersją. Opis młodej, cnotliwej, pięknej dziewczyny zmienionej w garstkę popiołu nasuwa skojarzenia z postacią tragicznie zmarłej księżniczki Teresy, córki Izabeli i Adama Kazimierza Czartoryskich.

Kolejny przykład omawianego w niniejszym artykule zjawiska stanowi oda opatrzona tytułem Do Anny Świętorzeckiej. Dwie siostry. Pierwsza wersja tego zamieszczonego w rękopisie pod wyżej wymienionym tytułem utworu została opublikowana w „Zabawach Przyjemnych i Pożytecznych” jako tetrastych zatytułowany Miłość, Wierność, będący przekładem epigramatu De amore et fide (Epigrammata II 15) Johna Owena ${ }^{34}$. Kolejną wersję omawianego liryku Kniaźnin zawarł w szóstej księdze Erotyków bez jakiejkolwiek dedykacji, jako wiersz Wierność i Miłośćc ${ }^{35}$, odwołujący się w tytule do alegorycznych wyobrażeń. Analogicznie do ukazanego poprzednio exemplum, również w przypadku tego utworu poeta podczas kolejnych redakcji zmieniał tytuły nowych wariantów pierwotnego tekstu. Już w Wierszach rzeczony utwór pojawia się pod innym, bardziej ogólnym i w związku z tym nieco tajemniczym tytułem: Dwie siostry ${ }^{36}$. Tytuł ten w Edycji zupetnej został rozszerzony o imię i nazwisko adresatki: Dwie siostry. Do Anny Świętorzeckiej ${ }^{37}$ (notabene Anna Świętorzecka ${ }^{38}$ wymieniona została wraz z mężem Józefem wśród subskrybentów tego wydania poezji Kniaźnina ${ }^{39}$ ). W autografie, tak jak w przypadku wielu innych liryków, poeta zmienił już tylko kolejność

${ }^{34}$ Por. E. Aleksandrowska, ,, Zabawy Przyjemne i Pożyteczne” 1770-1777. Monografia bibliograficzna, Instytut Badań Literackich, Warszawa 1999, s. 72.

${ }^{35}$ F. D. Kniaźnin, Wierność i Miłość, w: E, t. 2, s. 13-15.

${ }^{36}$ Tenże, Dwie siostry, w: W, s. 86-87.

${ }^{37}$ Tenże, Dwie siostry. Do Anny Świętorzeckiej, w: EZ, t. 1, s. 101-102.

${ }^{38}$ Anna Świętorzecka - z domu Heynik (Hennynk, Henynk), córka kamerdynera królewskiego, autorka przekładu powieści moralnej w „Zabawach Przyjemnych i Pożytecznych”, pierwsza żona Józefa Kazimierza Świętorzeckiego (poety, tłumacza, korespondenta politycznego, reprezentanta młodego pokolenia oświeconych), adresatka kilku jego wierszy wydrukowanych w tym periodyku. Zob. J. Platt, Józef Kazimierz Świętorzecki (1749 - po 1796), w: Pisarze polskiego oświecenia, t. 1, red. T. Kostkiewiczowa, Z. Goliński, Wydawnictwo Naukowe PWN, Warszawa 1992, s. 758; por. też Bibliografia literatury polskiej „Nowy Korbut”, t. 6: Oświecenie, cz. 1, oprac. E. Aleksandrowska z zespołem, Państwowy Instytut Wydawniczy, Warszawa 1970, s. 313.

${ }^{39}$ Zob. F. D. Kniaźnin, Subskrypcja, w: EZ, t. 1, s. VII. W zbiorach poezji Kniaźnina znajduje się także kilka wierszy dedykowanych Józefowi Świętorzeckiemu, co, podobnie jak umieszczenie 
poszczególnych członów: rozpoczął od wskazania osoby, której zadedykował swą odę, po czym dodał podtytuł Dwie siostry.

Zmiany nie dotyczą jednak tylko tytułów kolejnych wariantów tego utworu. Jego pierwowzór opublikowany w ,Zabawach Przyjemnych i Pożytecznych", jak już zostało nadmienione, to czterowiersz, przekaz z Erotyków liczy z kolei dziewięć strof czterowierszowych, natomiast pozostałe, wskazane powyżej warianty - osiem. W trakcie wprowadzania pierwszych zmian redakcyjnych w omawianym utworze poeta rozwinął myśl z epigramatu z „Zabaw Przyjemnych i Pożytecznych", rozbudowując go z jednej strofy do dziewięciu, a poruszany w pierwowzorze wątek zawarł w dwóch końcowych strofach nowo powstałego wiersza zamieszczonego w Erotykach. Podczas drugiej redakcji Kniaźnin zrezygnował z początkowych czterech wersów znajdujących się w Erotykach. W trzech strofach (drugiej - cytowanej w dalszej partii tekstu, trzeciej i szóstej) całkowicie zmienił jedną parę rymową i w znacznym stopniu zmodyfikował tekst. Warto dla jasności ukazać dokonane przez autora zmiany za pomocą tabelarycznych zestawień:

Pierwsza się z onych Miłością zwała, cały się do niej świat palił.

Druga Wierności nazwisko miała, każdy ją wielbił i chwalił.

(Wierność i Miłość, E, w. 9-12)

Dość jej umiała Wierność ulegać, bojąc się swojego cienia, nie śmiała nawet nigdzie wybiegać, dla siostry swej podejrzenia.

(Wierność i Miłość, E, w. 21-24)
Jedna z nich miała imię Miłości, cały się do niej świat palił.

Druga nazwisko wzięła Wierności, każdy ją lubił i chwalił. (Dwie siostry, W, w. 5-8)

Dość jej umiała Wierność ulegać, bojąc się cienia własnego, nie śmiała nawet okiem wybiegać, dla podejrzenia jakiego.

(Dwie siostry, W, w. 17-20)

Strofy czwarta i ósma zostały usunięte, a ich miejsce zajęły zupełnie inne:

Nie były nad nich siostry nawzajem, co by się bardziej kochały.

Rzadkim ta jedność jest obyczajem, Wierność i Miłość ją miały. (Wierność i Miłość, E, w. 13-16)

A tak, co niegdyś społecznym duchem pięknie się z sobą spoiły, Wierność i Miłość nagłym rozruchem waśnie i rozdział sprawiły.

(Wierność i Miłość, E, w. 29-32)
Pokój w ich domu trwał doskonały i stał na warcie u bramy, gdzie dwa gołąbki ten napis miały: „Z sobą się tylko kochamy".

(Dwie siostry, W, w. 9-12)

Zaraz skrzywiła wźrok na nią ostry, ta się nawzajem odwróci.

I tak na koniec dwie zgodne siostry mara jakowaś pokłóci.

(Dwie siostry, W, w. 25-28) 
Tylko jedna strofa (w Erotykach piąta) we wszystkich rozbudowanych wariantach brzmi prawie tak samo. W wersji z Wierszy po niewielkich zmianach stylistycznych znalazły się także strofy siódma i dziewiąta. W Poezjach. Edycji zupetnej dwie strofy (szósta i ósma) zostały zastąpione zupełnie innymi, natomiast w pozostałych poeta znacznie zmienił łącznie cztery wersy, poza tym wprowadził także drobne poprawki w innych miejscach. Przy opracowywaniu ostatniej, zawartej w rękopisie, wersji utworu poprawki autorskie były już właściwie kosmetyczne.

Porównując kolejne warianty ody Do Anny Świętorzeckiej. Dwie siostry, można zaobserwować (oprócz wymienionych przy okazji omawiania poprzedniego utworu, typowych dla poety zmian redakcyjnych, na przykład rezygnowania z motywów mitologicznych) także inne charakterystyczne poprawki, odróżniające odmiany tekstu wiersza pomieszczonego w Erotykach od tych zaobserwowanych w późniejszych zbiorach poezji Kniaźnina. Przede wszystkim autor odchodzi od umieszczania wyrazów bliskoznacznych w bezpośrednim sąsiedztwie i łagodzi niektóre nieadekwatne, nacechowane określenia ${ }^{40}$. W wariancie z Erotyków druga strofa brzmi następująco:

\footnotetext{
Nie było lepsze małżeństwo żadne, jak to Pokoju i Zgody.

Dwie im się córki piękne i ładne udały nad inne płody. (Wierność i Mitość, E, w. 5-8)
}

W kolejnych wersjach natomiast Pokój i Zgoda (E, w. 6) zostały zastąpione przez Szacunek i Cnotę (W, w. 2; EZ, w. 2), ich córki zaś są już charakteryzowane jedynie przymiotnikiem tadne. Ponadto dwa ostatnie wersy tej strofy, dość niefortunne pod względem składniowym i stylistycznym, były przekształcane stopniowo w dwóch redakcjach - początkowo do wariantu niezręcznego intonacyjnie - aż autor uzyskał zadowalający go zapis, niezmienny w Poezjach. Edycji zupetnej (EZ) i w rękopisie (A):

Urodzone z nich dwie córki ładne stały się celem pieszczoty. (Dwie siostry, W, w. 3-4)
Zrodzone razem dwie córki ładne były ich celem pieszczoty. (Dwie siostry. Do Anny Świętorzeckiej, EZ, w. 3-4; Do Anny Świętorzeckiej. Dwie siostry, A, w. 3-4)

W omawianych odmianach tekstu widoczne są także wahania składni, na przykład „bojąc się swojego cienia” (Erotyki) / „bojąc się cienia własnego” (późniejsze wydania).

${ }^{40}$ Więcej na temat tego rodzaju poprawek: T. Kostkiewiczowa, dz. cyt., s. 55-56, 64. 
Co ciekawe, ogólna tematyka utworu we wszystkich redakcjach jest taka sama. Poeta, wykorzystując chwyt personifikacji, ukazuje zależności między miłością a wiernością, czyli fundamentami związków uczuciowych. W kolejnych wariantach tekstu porusza także problem „kochania za bardzo”, które prowadzi do nieuzasadnionej zazdrości i nabierania bezpodstawnych podejrzeń względem ukochanej osoby, a co za tym idzie - do nieporozumień, rozżalenia, łez i niszczenia pięknej relacji. Warto jednak zwrócić uwagę na fakt, że wraz z przypisaniem wiersza konkretnej adresatce, za sprawą modyfikacji ostatniej strofy, zmienia się jego wymowa. W wariancie z Erotyków i Wierszy utwór kończy się raczej przygnębiającą konkluzją, że nawet zbytnia uległość i nadmierne starania w miłości nie uchronią kochanków przed podejrzliwością i zaborczością w stosunku do siebie nawzajem, co zwykle prowadzi do rozpadu związku. Z kolei w Poezjach. Edycji zupetnej i w autografie poety, jako że wiersz jest skierowany do mężatki, kryzys w relacji tytułowych dwóch sióstr zostaje zażegnany - dzięki szacunkowi i cnocie (które, podobnie jak we wcześniejszych wariantach miłość i wierność oraz pokój i zgoda, zostały upostaciowane, ujęte w sposób alegoryczny).

Wielokrotnie podkreślano już, że w obliczu tak wyraźnych różnic w badanych przekazach tekstów może nasuwać się uzasadniona wątpliwość, czy rzeczywiście należy je uznawać za warianty tego samego utworu, a nie za samoistne wiersze. Jak zauważa Andrzej Krzysztof Guzek:

\begin{abstract}
Niektóre z owych oboczności korespondują ze sobą tak wyraźnie, iż nie wahamy się twierdzić, że przedmiotem naszej uwagi jest tekst w odmiennej redakcji. [...] Często jednak pojawiają się tak duże rozbieżności, że wiersze uznać należy za równouprawnione. Są wreszcie i wypadki pośrednie, zmuszające do teoretycznych rozważań nad ontologią i tożsamością tekstu literackiego, bez uzgodnienia zasady trudno decydować, czy są to dwa różne teksty, czy jeden w dwu postaciach ${ }^{41}$.
\end{abstract}

Ze względu na taki stan rzeczy wydawca dzieł Kniaźnina niejednokrotnie staje przed trudnym wyborem, musi wykazywać się ostrożnością i czujnością, nie może ponadto nabrać absolutnej pewności, że jego decyzje są jedynymi słusznymi, zwłaszcza że spotyka się z różnymi poglądami badaczy na ten temat ${ }^{42}$.

${ }^{41}$ A. Guzek, Nota edytorska, w: F. D. Kniaźnin, Wiersze wybrane, Państwowy Instytut Wydawniczy, Warszawa 1981, s. 200-201.

${ }^{42}$ Przykładem niech będzie kwestia pierwodruku Ody do wąsów. Wacław Borowy oraz Tadeusz Mikulski jako pierwszy wariant tego wiersza uznają wydanie z Erotyków (zob. W. Borowy, Wstęp, w: F.D. Kniaźnin, Wybór poezji, Wydawnictwo Narodowego Zakładu im. Ossolińskich, Wrocław 1948, s. 22-23; T. Mikulski, dz. cyt., s. 253). Z kolei Ludwik Kalisz w swej rozprawie Liryka Kniaźnina a poezja klasyczna stwierdza, że utwór ten po raz pierwszy ukazał się w Wierszach. W tym zbiorze badacz sytuuje także pierwodruk m.in. omawianego w niniejszej rozprawie liryku O Filorecie. Trudno jednak jednoznacznie stwierdzić, czy Kalisz uznał Grób Klimeny oraz 
W omawianej w niniejszym tekście edycji przyjęto nadrzędną zasadę, iż jeśli po wnikliwej lekturze w liryku obranym za podstawę wydania możliwe jest wskazanie stadium przejściowego oraz elementów niezmiennych i rozpoznanie w nim wypowiedzi literackiej, zamieszczonej w poprzednich zbiorach, należy te utwory uznawać za warianty ${ }^{43}$. W przypadku liryków z czterech pierwszych ksiąg rękopisu za takim postępowaniem może przemawiać również fakt, iż poeta nigdy nie zamieścił w jednym zbiorze dwóch utworów, które wydawca mógłby uznać za odmiany jednego tekstu.

W opisanych powyżej przypadkach pojawia się zatem pytanie: jak rozwiązać problem kolacjonowania odmian tekstów różniących się od siebie w tak znacznym stopniu, biorąc pod uwagę fakt, że sygnalizowanie ich, poprzez zestawianie słowo po słowie i wers po wersie dwóch różnych wydań, jest w tej sytuacji niemożliwe. Bez wątpienia tam, gdzie da się porównać lekcje i nie łączy się to z podawaniem w aparacie krytycznym tekstu całego utworu, należy zastosować tradycyjną metodę kolacjonowania, natomiast w pozostałych przypadkach najlepszym rozwiązaniem wydaje się zamieszczenie w Aneksie wariantów liryków z poprzednich zbiorów poety.

Edytor musi podjąć jednak kolejną trudną decyzję, dotyczącą zawartości owego Aneksu. Można przyjąć tu zasadę, że w Aneksie zostaną zamieszczone wyłącznie warianty tekstu, których w żaden inny sposób nie da się skonfrontować z odmianą danego liryku występującą w obranej podstawie wydania (tj. w autografie). W omówionych powyżej przypadkach w Aneksie znalazłyby się zatem wyłącznie liryki opublikowane w „Zabawach Przyjemnych i Pożytecznych” oraz w Erotykach. Pozostałe odmiany tych tekstów należałoby natomiast zasygnalizować w aparacie krytycznym, wykorzystując tradycyjną metodę kolacjonowania. Inna możliwość postepowania w przypadku liryków tego typu sprowadzałaby się do zamieszczenia w Aneksie wszystkich wariantów danego tekstu, którymi dysponuje wydawca.

Bez wątpienia za atuty pierwszego rozwiązania uznać można skondensowanie zapisu, jego przejrzystość oraz ułatwienie czytelnikowi dostrzeżenia różnic w tekstach, a także największe zbliżenie do tradycyjnej, ogólnie przyjętej metody kolacjonowania, z niewielkim tylko odstępstwem. Warto przy tym jednak zaakcentować za Konradem Górskim, że: „Celem tego zabiegu ma być dostarczenie materiału do odtworzenia procesu twórczego, do nakreślenia wyczerpującej historii, jak dzieło powstało"44. Wydaje się, że zaproponowana metoda może

Wasy zamieszczone w Erotykach za odrębne utwory, czy też uszły one jego uwadze podczas lektury i nie dostrzegł ich zbieżności z wierszami z późniejszych zbiorów, w których został podjęty ten sam temat (zob. tenże, dz. cyt., s. 45-46).

${ }^{43}$ Zob. także: B. Prokopczyk, Odmiany tekstu i problemy edycji wybranych sielanek Franciszka Dionizego Kniaźnina, w: Warsztaty Młodych Edytorów, Koło Naukowe Edytorów UJ, Rabka 2013, s. 73-83.

${ }^{44}$ K. Górski, Tekstologia i edytorstwo dzieł literackich, Państwowe Wydawnictwo Naukowe, Warszawa 1978, s. 97. 
spowodować zaciemnienie tego obrazu, jako że warianty danego tekstu zostaną rozbite poprzez usytuowanie ich $\mathrm{w}$ dwóch różnych miejscach publikacji, a aparat krytyczny będzie zawierał wówczas niekompletny materiał dokumentacyjny. Prześledzenie kolejno wprowadzanych przez autora zmian stanie się dla odbiorcy trudniejsze i niewygodne. $Z$ tego powodu należałoby się skłaniać raczej ku drugiemu rozwiązaniu, jako że umożliwia ono ukazanie pełnego procesu powstawania danego utworu. Ponadto dzięki zastosowaniu takiego zapisu łatwiejsze staje się dostrzeżenie etapów wprowadzania zmian redakcyjnych przez autora oraz elementów tożsamych dla wszystkich wariantów tekstu, a co za tym idzie - nabranie pewności, że mamy do czynienia z odmianami tego samego utworu, a nie z odrębnymi dziełami.

Trzeba w tym miejscu zasygnalizować, że osobliwość zapisów i przypadków, mnogość możliwości oraz liczba przekazów wierszy puławskiego twórcy i brak jednoznacznych wytycznych implikują konieczność wnikliwego rozpatrywania wielu kwestii, niekiedy uniemożliwiając edytorowi tekstów utworów zamieszczonych w autografie Kniaźnina podążanie utartymi ścieżkami, i zmuszają go do podejmowania trudnych decyzji oraz postępowania w sposób nowatorski. Dyskusja nad zasadami, które powinny zostać przyjęte podczas przygotowywania do druku tak obszernego i skomplikowanego materiału źródłowego, pozostaje sprawą otwartą. Pod rozwagę badaczy twórczości Kniaźnina i wnikliwych czytelników utworów puławskiego poety warto poddać kwestię, czy w odniesieniu do omówionych tu problemów istnieje jakieś lepsze rozwiązanie. Należy przy tym podkreślić, że celem wydawcy testamentu poetyckiego puławskiego twórcy powinno być przede wszystkim przygotowanie rzetelnej, przystępnej dla odbiorców edycji, jak najwierniej odzwierciedlającej drogę, jaką przebył autor, by uzyskać ostateczny kształt swych dzieł, przy jednoczesnym uszanowaniu jego woli.

\section{Bibliografia}

\section{Podmiotowa}

Kniaźnin Franciszek Dionizy, Erotyki, t. 1-2, wyd. w Drukarni Nadwornej J.K. Mci, Warszawa 1779.

Kniaźnin Franciszek Dionizy, Miłość, wiernossć, „Zabawy Przyjemne i Pożyteczne” 1773, t. 8, cz. 2, s. 368.

Kniaźnin Franciszek Dionizy, Poezje. Edycja zupełna, t. 1-3, wyd. w Drukarni uprzywilejowanej Michała Grölla, Księgarza Nadwornego J.K. Mci, Warszawa 1787-1788.

Kniaźnin Franciszek Dionizy, Wiersze, t. 1, wyd. nakładem i drukiem Michała Grölla, Księgarza Nadwornego J. K. Mci, Warszawa 1783.

\section{Przedmiotowa}

Aleksandrowska Elżbieta, „Zabawy Przyjemne i Pożyteczne” 1770-1777. Monografia bibliograficzna, Instytut Badań Literackich, Warszawa 1999.

Bibliografia literatury polskiej „Nowy Korbut”, t. 6: Oświecenie, cz. 1, oprac. Elżbieta Aleksandrowska z zespołem, Państwowy Instytut Wydawniczy, Warszawa 1970. 
Borowy Wacław, Wstęp, w: Franciszek Dionizy Kniaźnin, Wybór poezji, Wydawnictwo Narodowego Zakładu im. Ossolińskich, Wrocław 1948, s. 5-37.

Górski Konrad, Tekstologia i edytorstwo dzieł literackich, Państwowe Wydawnictwo Naukowe, Warszawa 1978.

Grimal Pierre, Słownik mitologii greckiej i rzymskiej, przeł. Maria Bronarska, Barbara Górska, Anna Nikliborc, Joanna Sachse, Olga Szarska, red. nauk. J. Łanowski, Zakład Narodowy im. Ossolińskich, Wrocław 1987.

Guzek Andrzej, Nota edytorska, w: Franciszek Dionizy Kniaźnin, Wiersze wybrane, Państwowy Instytut Wydawniczy, Warszawa 1981, s. 200-207.

Kalisz Ludwik, Liryka Kniaźnina a poezja klasyczna, „Pamiętnik Literacki” 1924/25, R. XXI, s. $42-60$.

Kostkiewiczowa Teresa, Kniaźnin jako poeta liryczny, Zakład Narodowy im. Ossolińskich - Wydawnictwo Polskiej Akademii Nauk, Wrocław-Warszawa-Kraków-Gdańsk 1971.

Mikulski Tadeusz, Nad tekstami Kniaźnina, w: tegoż, W kręgu oświeconych, Państwowy Instytut Wydawniczy, Warszawa 1960, s. 247-326.

Platt Julian, Józef Kazimierz Świętorzecki (1749 - po 1796), w: Pisarze polskiego oświecenia, t. 1, red. T. Kostkiewiczowa, Z. Goliński, Wydawnictwo Naukowe PWN, Warszawa 1992, s. 756-761.

Prokopczyk Beata, Odmiany tekstu i problemy edycji wybranych sielanek Franciszka Dionizego Kniaźnina, w: Warsztaty Młodych Edytorów, Koło Naukowe Edytorów UJ, Rabka 2013, s. $73-83$.

Rabowicz Edmund, Stanisław Trembecki w świetle nowych źródeł, Zakład Narodowy im. Ossolińskich, Wrocław-Warszawa-Kraków 1965.

Zimorowic Józef Bartłomiej, Sielanki nowe ruskie, oprac. L. Szczerbicka-Ślęk, Zakład Narodowy im. Ossolińskich, Wrocław 1999, BN I 287.

\section{Beata Bednarek}

\section{Collation of sources poems by Franciszek Dionizy Kniaźnin based on selected lyrics contained in the poet's autograph - editorial dilemmas}

\section{(Summary)}

Franciszek Dionizy Kniaźnin has created manuscript for a few years. It was a kind of his poetical will. In this collection, titled Poezje Franciszka Dionizego Kniaźnina ręka własna pisane, author included works published in three previous collections volumes of verse as well as completely new poems. Reused works had many editorial alterations compared to original ones. First time published works had been totally unknown before. Poezje Franciszka Dionizego Kniaźnina ręka wtasna pisane was not published as printed, scientific edition yet. This article describes today's editor dilemmas about making a critical edition of four first book contained in the first volume of autograph. Mainly it is focused on the problem of comparasion variants of particular texts, which often are very different.

Keywords: critical edition; autograph; collation; text's variants

Słowa kluczowe: edycja krytyczna; autograf; kolacjonowanie; odmiany tekstu 